\title{
RANKING THE CAUSATIVE FACTORS OF MORTGAGE VALUATION INACCURACY IN KADUNA METROPLOIS
}

\author{
Bilkisu Adamu Aliyu, M.Sc. \\ Department of Real Estate and Valuation \\ Nuhu Bamalli Polytechnic, Zaria, Nigeria \\ e-mail: bilkiadamu001@gmail.com \\ Habibu Sani, PhD \\ Department of Real Estate and Valuation \\ Kaduna Polytechnic, Kaduna State, Nigeria \\ e-mail: sanihavibu@gmail.com \\ Hamza Usman \\ Department of Real Estate and Valuation \\ Abubakar Tafawa Balewa Bauchi, Nigeria \\ e-mail:hamzeeusm@gmail.com

\section{Hassan Muhammad} \\ Department of Real Estate and Valuation \\ NuhuBamalliPolytechnic, Zaria, Nigeria \\ e-mail:hmuhammad608@gmail.com
}

\begin{abstract}
This paper is aimed at contributing to the scarce empirical literature on mortgage valuation by ranking the factors that influences mortgage valuation inaccuracy in the Kaduna Residential property market. A quantitative research approach using a survey design was adopted and structured closedended questionnaires were designed and administered to 57 registered Estate Surveying and Valuation (ESV) firms in Kaduna metropolis; 51 out of the 57 administered questionnaires were returned and used for analysis. A simple random sampling technique was employed and the 5-point Likert scale used as the scale of measurement, while causative factors were ranked using the Relative Importance Index (RII). The study analyzed the data using percentages. Findings indicated that data inadequacy, imperfection in the property market and clients' pressure are the most trending in the absence of a unified valuation approach. The regulatory framework and valuation methodology are least contributory to valuation inaccuracy in the study area. The research will be of interest to practitioners and academic researchers interested in mortgage valuation as a guide for conducting mortgage valuation in the study area.
\end{abstract}

Keywords: Mortgage, Valuation, Property Market, valuation inaccuracy, estate surveyors.

JEL Classification: G21, D70.

Citation: Aliyu B.A., Sani H., Usman H., Muhammad H., 2018, Ranking the Causative Factors of Mortgage Valuation Inaccuracy in Kaduna Metroplois, Real Estate Management and Valuation, vol. 26, no. 3, pp. 71-81.

DOI: $10.2478 /$ remav-2018-0026 


\section{Introduction}

Recent concerns in the sphere of property valuation regard the quality of residential property valuation as a compelling intermediary tool for benchmarking property deals, thus overwhelmingly witnessing extensive attention and, thereby, provoking open deliberation in the UK, US, Canada and Australia (BROWN, MATYSIAK 2000; OGUNBA 2007). Indeed, even in nations where portfolio management is in its early stage, clients generally rely on valuation opinions to make decisions on mortgage, insurance, and for other purposes. Such clients expect valuation opinions to provide an accurate basis for their investment decisions. Attempts are being made, especially in advanced nations, to ascertain the accuracy of valuations carried out. Though these results are not yet final, there is at least an effort to investigate accuracy and find out if there is a need for remedial action (BABAWALE, OMIRIN 2012). The requirement for precision and corrective action is not limited to advanced nations, as all nations require investigative studies to recommend how their valuation profession can be perfected so that its customers can confidently base their decisions on valuation estimates (OGUNBA2007). With the formation and diversity of industrial and commercial economic activities, and given the prime role property holdings play, particularly as a guarantee for the release/production of capital funds, the corresponding role of valuation can only be directly increasingly proportional. However, since most human endeavors are fraught with disputes, claims and counterclaims, the practice of valuation is no exception. Thus, more often than not, situations may arise when valuation figures become suspicious, as clients find it difficult to sell at the appraised value when eventually offered to the market for disposal. On the other hand, some clients suffer the negative consequences of inaccuracy when their properties are disposed of at values lower than the real market price. Such inaccuracy does not portray professionalism, as it affects the perception of clients and the general public on valuers integrity, thereby ascribing guess-work as the basis of valuation assessments employed by valuers. This in turn generates suspicion about the competence and credibility of appraisers. It also creates a gateway for charlatans to enter the profession (ADEGOKE 2016; AKINJARE et al. 2013). Incursions by other professionals into the realm of property valuation in Nigeria may be connected with the perception that valuations are matters of guesswork.

Hence, in the past, engineers claimed to be the best fit professionals to value plants and machinery, while accountants and bankers believe that the conventional valuation methods are shrouded in mystery and indefensible. The average layman believes that valuers' advice is driven by the quest to earn higher fees since the payment of fees is based on assessed values. While it has been agreed that valuation is imprecise, and thus some level of inaccuracy and variation is to be expected, it is equally important to ensure that valuation is close to the sale price, so that it can play the essential role that it ought to on the property market (AYEDUN 2009; AJIBOLA 2010; ADEGOKE 2016). If this issue is not finally addressed, a widespread rejection of valuers' judgment of value may occur and impinge severely on the Nigerian valuation profession.

One reason as to why valuation opinions are required are mortgage transactions, although the Nigerian mortgage market is not fully developed as evidenced by less than 100,000 transactions between 1960 and 2009 (a period of about 50 years). Analysis of mortgages in relation to the available funds for mortgage loan as of 2009 averaged a dismal 14.51\%, while the total capital market is up to N127.5 billion (US $\$ 850$ million). Contribution of mortgage finance to Nigeria's GDP is close to negligible, with real estate contributing less than $5 \%$, and mortgage loans and advances at $0.5 \%$ of GDP (WALLEY2009) as further indicated by a recent report of the Ministry for Lands, Housing and Urban Development, which put Nigeria's debt to mortgage ratio at a dismal $4 \%$ of Nigeria's debt (PEEBLE2012). This underscored the need for mortgage valuations to be accurate.

Previous research concerned the inaccuracy of valuation based on property type (OluFOLAHANet al. 2016) and sale purpose of valuation (BABAWALE 2008), whereas (AYEDUN 2009) focused on auction valuation, and (SHEHU 2016) - on factors affecting the inaccuracy of valuation in general, without narrowing it down to the purpose of valuation. However, (ADEGOKE et al. 2013) revealed clients' dissatisfaction with the reliability of mortgage valuation evidenced by large disparity between the opinion regarding value and sales prices on foreclosed mortgage properties. Similarly, (OSMOND, HARCOURT 2014) opined that valuers neglect valuation standards in the course of their assignment as a result of inadequate supervision by subordinates assigned by the head of the firm, with this being a reason for valuation inaccuracy. Other factors contributing to valuation inaccuracy are; dearth of 
rental evidence and inaccurate capitalization rate (AYEDUN2009). Worsening the phenomenon is noncompliance with the standards of the practice and procedures in arriving at the opinion of values in some cases and resorting to hiking up their opinions of values with a view to satisfy the mortgagor's demand, who in-turn pay gratification (BABAWALE, OMIRIN 2012; EFFIONG 2015; MuNSHIFWA et al. 2016).

It is therefore clear that previous studies were on valuation accuracy in general, without the extensive assessment of factors influencing inaccuracy in mortgage valuation within Kaduna metropolis. This paper therefore seeks to bridge the gap by assessing and ranking the influential factors affecting mortgage valuation inaccuracy in Kaduna, with a view to improvie the quality of the mortgage valuation practice.

\section{Literature review}

The topic of valuation accuracy, reliability and variance has been a focus of research in the real estate profession for quite some decades now (ROSSINI 1999; KUCHARSKA - STASIAK 2013). Debate on valuation accuracy continued to receive attention from the academia, practitioners and other stakeholders in the real estate business circle, triggered by the pioneer works of HAGER and LORD (1985), who invited valuers to value two properties in the UK, the result of which provided for the range of $+/-5$ on either side of the correct value. The study of Hager and Lord was immediately followed by that of BROWN (1985) who used the regression model to relate transaction price with the previously conducted valuation estimates on a small sample size of 29 properties in the UK and concluded that the valuations were good proxy of sales price in the UK. Subsequently, in 1987, Drivers Jonas commissioned Investment Property Databank (IPD) to carryout empirical research into valuation accuracy in the UK using large samples of properties (IPD/DJ, 1988). The study found that sales prices are closely related to valuation estimates. However, WALDY (1997) questioned the integrity of the findings on valuation accuracy and advocated for behavioral research to complement valuation accuracy debates. Developments in the UK on valuation accuracy transcend to the US, where COLE, GUILKEY and MiLES (1986) and FERGUSON (1988) conducted similar studies, which they concluded by questioning the reliability of valuation estimates (ALUKO 2004). In Australia, (PARKER 1998), using a small sample size and a case study, found correlations between sales prices and valuation estimates.

Findings on valuation accuracy in developed markets show a high level of accuracy; the case is different, however, with emerging property markets. For instance, in Nigeria, AJIBOLA(2006) conducted a study on the accuracy of valuation in Lagos state with a reported margin of error on valuation figures of between $+24.82 \%$ and $+51.54 \%$ for Ikoyi and Ojodu areas of Lagos State respectively. OGUNBA and AJAYI(1998), on the other hand, found a margin of $-33.43 \%$ and $36.47 \%$ for Victoria Island and Ikoyi respectively. All these margins exceed the established $+15 \%$ acceptable margin of error, thus pointing to a worse scenario in Nigeria when compared to the UK and US. ALUKO (2000) conducted research on mortgage valuation and subsequent sale prices of mortgaged properties used as collateral securities based on bank records of mortgage valuations conducted by fifty-nine (59) estate surveying and valuation firms in Lagos Metropolis. The sale prices of the properties were compared with their earlier valuation estimates and analyzed by means of regression/ANOVA; a conclusion was drawn that valuation in Nigeria is a good proxy for price; nonetheless, different findings were reported by (AJIBOLA 2010), i.e. that mortgage valuation in Nigeria is not a good proxy for sale prices on foreclosed properties.

Similarly, ALUKO(2004)conducted a study on the reliability of valuations for mortgage purposes; the study examined open market valuations as a good proxy for prices in Lagos metropolis through an interview conducted among 42 lending institutions and 59 estate surveying and valuation firms, using stratified sampling on transactions entered into between January 1994 to December 2002. The results show that the relationship between the values and the prices of properties sampled was $78 \%$, and was significant at P-Value of [0.0000]. It concluded that the evidence from regression analysis showed accuracy in open market valuation for mortgages, and thus a good proxy for predicting market prices, although the accuracy is not as high as in the UK, USA and Australia. ALUKO (2004) also noted that value should be reported as a range rather than a single point estimate, further stating that valuers may adopt statistical analysis in their valuations to improve valuation accuracy and reliability in value predication. 


\section{S sciendo}

Moreover, (OLUWUNMI et al. 2011) studied client's satisfaction on mortgage valuation reports in Nigeria and reported that mortgage valuation practitioners require a search for additional information for improved output to conform with the best practice standards, as required of the valuer to provide adequate, appropriate and relevant information which the bank may rely upon to grant mortgages. The results showed that mortgage valuation reporting has not produced optimum satisfaction of clients, thus concurring with previous researchers. The aforementioned review demonstrated that the bulk of mortgage valuation research revolved around valuations for the determination of open market value in residential properties. Little attention was paid to causative factors responsible for valuation inaccuracy in mortgage valuation. It is, therefore, necessary to extend to the root of this issue by presenting a challenge to practicing surveyors in the study area to assess the extent to which those factors affect mortgage valuation accuracy in the residential property market, in order to enrich existing literature on the subject matter by revealing the proportional contribution of each factor in influencing mortgage valuation accuracy as presented in Table 1 below, based on the adopted coding: (F1) valuation methodology, (F2) problems of relevant data, (F3) client pressure, (F4) Effective regulatory framework, (F5) absence of national valuation standards, (F6) skills, experience and judgment of valuers (F7), the integrity of the individual valuer, (F8) characteristics of the property market (F9) valuation assumptions, (F10) familiarity with the property market, and (F11) errors in the survey, and (F12) negligence.

Table 1

Factors Influencing Mortgage Valuation Accuracy: content analysis of valuation report

\begin{tabular}{|c|c|c|c|c|c|c|c|c|c|c|c|c|c|}
\hline $\begin{array}{l}\mathrm{S} / \\
\mathrm{N}\end{array}$ & Authors & 厌 & N & $\mathscr{I}$ & 孛 & 量 & 居 & 仝 & $\stackrel{\infty}{\infty}$ & 空 & $\underset{I}{\stackrel{ }{I}}$ & $\overrightarrow{I I}$ & $\underset{I}{\stackrel{T}{I}}$ \\
\hline 1 & ELEKWACHI et al. (2016) & $\sqrt{ }$ & & & & & & & & & & & \\
\hline 2. & ODUYEMI et al.(2016) & $\sqrt{ }$ & $\sqrt{ }$ & $\sqrt{ }$ & $\sqrt{ }$ & $\sqrt{ }$ & $\sqrt{ }$ & $\sqrt{ }$ & $\sqrt{ }$ & $\sqrt{ }$ & & & \\
\hline 3. & ADEGOKE(2016) & $\sqrt{ }$ & & & $\sqrt{ }$ & & & & & $\sqrt{ }$ & & & \\
\hline 4 & ACHU et al.(2015) & & & $\sqrt{ }$ & & & & & & & & & \\
\hline 5. & CHUKWUMA et al. (2015) & & & $\sqrt{ }$ & & & & & & & & & \\
\hline 6. & EFFIONG (2015) & $\sqrt{ }$ & & & & & & & & & & & \\
\hline 7. & OLAFA (2015) & $\sqrt{ }$ & $\sqrt{ }$ & $\sqrt{ }$ & & & $\sqrt{ }$ & & & & & & $\sqrt{ }$ \\
\hline 8. & ADEGOKE(2015) & $\sqrt{ }$ & & $\sqrt{ }$ & & & $\sqrt{ }$ & & & & & $\sqrt{ }$ & \\
\hline 9. & OSMOND and HARCOURT (2014) & $\sqrt{ }$ & & $\sqrt{ }$ & & & & & & $\sqrt{ }$ & & & \\
\hline 10. & Bowcock (2015) & & & & & & & & & & & $\sqrt{ }$ & \\
\hline 11. & ADEGOKE et al.(2013) & & & & & & $\sqrt{ }$ & & & & & & \\
\hline 12. & BABAWALE and ALABI(2013) & & & & & & & & $\sqrt{ }$ & & & $\sqrt{ }$ & \\
\hline 13. & BABAWALE (2013) & & $\sqrt{ }$ & $\sqrt{ }$ & & $\sqrt{ }$ & & & & & $\sqrt{ }$ & & \\
\hline 14 & BABAWALE (2013) & $\sqrt{ }$ & $\sqrt{ }$ & $\sqrt{ }$ & $\sqrt{ }$ & & $\sqrt{ }$ & & $\sqrt{ }$ & & & & \\
\hline 15 & ACHU (2013) & & & $\sqrt{ }$ & & & & & & & & & \\
\hline 16 & AYEDUN et al. (2012) & & $\sqrt{ }$ & & & & & & & & & & \\
\hline 17 & GABRIEL and OMIRIN (2012) & & & & & & $\sqrt{ }$ & & & $\sqrt{ }$ & & & \\
\hline 18 & BABAWALE and AJAYE (2011) & & & & & & & & & & & & \\
\hline 9 & AJIBOLA (2011) & $\sqrt{ }$ & $\sqrt{ }$ & $\sqrt{ }$ & & & $\sqrt{ }$ & & & & & & $\sqrt{ }$ \\
\hline 20 & GABRIEL and OMIRIN(2012) & & $\sqrt{ }$ & $\sqrt{ }$ & & $\sqrt{ }$ & $\sqrt{ }$ & & & $\sqrt{ }$ & $\sqrt{ }$ & & \\
\hline \multirow[t]{2}{*}{21} & PETER (1991) & & $\sqrt{ }$ & & & & $\sqrt{ }$ & & & & & & \\
\hline & Total & 8 & 8 & 11 & 3 & 3 & 9 & 1 & 3 & 5 & 2 & 3 & 2 \\
\hline
\end{tabular}

Source: Field survey 2017.

\section{Data and methods}

The study was mainly based on the quantitative approach, utilizing survey research. The study population was primarily the estate surveyors and valuers practicing within Kaduna City; 67 registered firms in Kaduna metropolis form the sampling frame from which a sample size of 57 was drawn using Yammane's formula as follows: 


$$
\text { Sample size }=\frac{N}{1+N(e)^{2}}=\frac{67}{1+67(0.05)^{2}}=57
$$

A simple random sampling technique was used to select the 57 samples as representative of the population. Data was collected using structured close-ended questionnaires, which were initially administered in a pilot test; observations were collated and amendments were made before producing the final improved version administered on the study population. Of the 57 distributed questionnaires, 51, representing 90 percent, were considered valid for data analysis. The reliability of the instrument was tested using Cronbach's alpha coefficients. The instrument is considered reliable, as all the items have an alpha value above the recommended minimum of 0.7 (PALLANT2011).

The results of the analysis have been presented in percentages. Relative importance of the factors is calculated using the Relative Importance Index (RII) formula below.

$$
\text { Relative Importance Index }(\mathrm{RII})=\frac{\sum W}{A x N}
$$

where, $\sum W$ is the sum of the weighted individual responses, $\mathrm{A}$ is the highest response value, in this case 5 since the 5-point Likert scale was used to collect the data, and $\mathrm{N}$ is the sample size. This can alternatively be calculated using the following formula:

$$
R I I=\frac{n 1+2 n 2+3 n 3+4 n 4+5 n 5}{5(n 1+2 n 23 n 3+4 n 4+5 n 5)}
$$

The values obtained from RII range from 0 to1, with 1 representing perfect importance. In other words, the closer the RII value is to 1 , the higher its importance and vice versa.

\section{Empirical results}

\subsection{Respondents' profile}

The profile of the respondents is presented in the table below.

Table 2

Education

\begin{tabular}{lll}
\hline & Frequency & Percent \\
\hline HND & 17 & 33.3 \\
\hline B.Sc & 26 & 51.0 \\
\hline M.Sc & 5 & 9.8 \\
\hline Ph.D & 3 & 5.9 \\
\hline Total & 51 & 100.0 \\
\hline
\end{tabular}

Source: Field survey 2017.

Table 2 shows that majority of the respondents are B.Sc degree holders as indicated by 51 percent declaring so, and HND (Higher National Diploma) holders amounting to 33.3 percent. Only 9.8 percent and 5.9 percent hold M.Sc. and Ph.D. degrees respectively. Similarly, Table 3 shows that 64.7 percent of the respondents are Associates of the Nigerian Institution of Estate Surveyors and Valuers (NIESV), followed by probationers of the institution. However, only 5.9 percent are FNIVS members.

Professional Qualifications

Table3

\begin{tabular}{lll}
\hline & Frequency & Percent \\
\hline ANIVS & 31 & 64.7 \\
\hline FNIVS & 3 & 5.9 \\
\hline Probationer & 15 & 29.4 \\
\hline Total & 51 & 100.0 \\
\hline
\end{tabular}




\section{S sciendo}

Source: Field survey 2017.

The majority of the respondents, as shown in Table 4 below, are principal partners of their firms, representing 31.4 percent. Another 25.5 percent are managers and branch heads, respectively. The remaining 17.6 percent of the respondents represent other positions.

Table 4

Position occupied

\begin{tabular}{lll}
\hline & Frequency & Percent \\
\hline Principal partner & 16 & 31.4 \\
\hline Manager & 13 & 25.5 \\
\hline Branch head & 13 & 25.5 \\
\hline Others & 9 & 17.6 \\
\hline Total & 51 & 100.0 \\
\hline
\end{tabular}

Source: Field survey 2017.

Table 5 below indicated that all the respondents are members of NIESV, as shown by 100 percent affirmative responses, while only 11.8 percent are members of RICS. However, none of the respondents are members of CASLE, IREF, AREI, RVA, IRRV or RSA.

Table 5

Membership of Real Estate Professional Bodies

\begin{tabular}{lcc}
\hline Professional Bodies & Yes (\%) & No. (\%) \\
\hline Nigerian Institution of Estate Surveyors and Valuers (NIESV) & $51(100)$ & $0(0)$ \\
\hline Royal Institute of charted Surveyors (RICS) & $6(11.8)$ & $45(88.2)$ \\
\hline $\begin{array}{l}\text { Common Wealth Association of Surveyors and Land Economy } \\
\text { (CASLE) }\end{array}$ & $0(0)$ & $51(100)$ \\
\hline International Real Estate Federation (IREF) & $0(0)$ & $51(100)$ \\
\hline America Real Estate Institute (AREI) & $0(0)$ & $51(100)$ \\
\hline Rating and Valuation Association (RVA) & $0(0)$ & $51(100)$ \\
\hline Institute of Revenue Rating and Valuation (IRRV) & $0(0)$ & $51(100)$ \\
\hline Rating Surveyors Association (RSA) & $0(0)$ & $51(100)$ \\
\hline
\end{tabular}

Source: Field survey 2017.

Table 6 below shows the type of valuations typically carried out by real estate firms in Kaduna. It shows that the most common valuation is mortgage valuation, followed by sales, rental, asset, insurance, rating, probate and for balance sheet purposes, as ranked $1^{\text {st }}$ to $8^{\text {th }}$ respectively.

Table 6

Valuations carried out by firms most frequently

\begin{tabular}{|c|c|c|c|c|c|c|}
\hline & $\begin{array}{l}\text { Very often } \\
\text { (4) }\end{array}$ & Often (3) & Rarely (2) & $\begin{array}{l}\text { Not at all } \\
\text { (1) }\end{array}$ & RII & Rank \\
\hline Mortgage valuation & $26(51)$ & $14(27.5)$ & $11(21.6)$ & - & 0.82 & $1^{\text {st }}$ \\
\hline Sales valuation & $22(43.1)$ & $22(43.1)$ & $4(7.8)$ & $3(5.9)$ & 0.81 & $2^{\text {nd }}$ \\
\hline Rental Valuation & $17(33.3)$ & $23(45.1)$ & $7(13.7)$ & $4(7.8)$ & 0.76 & $3^{\text {rd }}$ \\
\hline Asset valuation & $5(9.8)$ & $25(49)$ & $18(35.3)$ & $3(5.9)$ & 0.67 & $4^{\text {th }}$ \\
\hline Insurance valuation & $7(13.7)$ & $21(41.2)$ & $19(37.3)$ & $4(7.8)$ & 0.65 & $5^{\text {th }}$ \\
\hline Rating valuation & - & $10(19.6)$ & $24(47.1)$ & $17(33.3)$ & 0.47 & $6^{\text {th }}$ \\
\hline Probate valuation & $1(2.0)$ & $3(5.9)$ & $28(54.9)$ & $19(37.3)$ & 0.43 & 7 th \\
\hline Valuation for balance sheet & $1(2.0)$ & $5(9.8)$ & $15(29.4)$ & $30(58.8)$ & 0.39 & $8^{\text {th }}$ \\
\hline
\end{tabular}

Source: Field survey 2017.

\subsection{Factors influencing mortgage valuation inaccuracy in Kaduna metropolis}

The ranking of the factors affecting mortgage valuation inaccuracy in the Kaduna residential property market has been presented in Table 7 below. 


\section{S sciendo}

Table 7

Factors influencing mortgage valuation inaccuracy

\begin{tabular}{|c|c|c|c|c|c|c|c|}
\hline 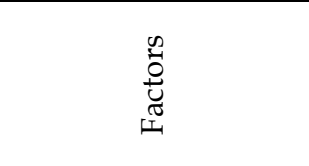 & 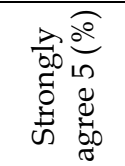 & 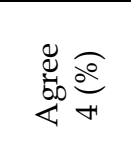 & 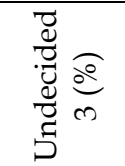 & 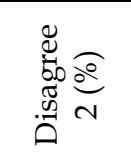 & 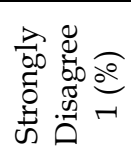 & RII & 光 \\
\hline $\begin{array}{l}\text { Problems of relevant } \\
\text { data }\end{array}$ & $30(58.8)$ & 18(35.3) & - & $3(5.9)$ & - & 0.89 & $1^{\text {st }}$ \\
\hline $\begin{array}{l}\text { Valuation } \\
\text { methodology }\end{array}$ & $26(51)$ & $23(45.1)$ & $1(2)$ & $1(2)$ & - & 0.89 & $2^{\text {nd }}$ \\
\hline Client pressure & $5(9.8)$ & $40(78.4)$ & $2(3.9)$ & $4(7.8)$ & - & 0.78 & $3^{\text {rd }}$ \\
\hline $\begin{array}{l}\text { Skills, experience } \\
\text { and judgment of the } \\
\text { valuer }\end{array}$ & $18(35.3)$ & $13(25.5)$ & $17(33.3)$ & - & $3(5.9)$ & 0.77 & $4^{\text {th }}$ \\
\hline $\begin{array}{l}\text { Regulatory } \\
\text { framework }\end{array}$ & $8(15.7)$ & $23(45.1)$ & $15(29.4)$ & $5(9.8)$ & - & 0.73 & $5^{\text {th }}$ \\
\hline $\begin{array}{l}\text { Characteristic of the } \\
\text { property market }\end{array}$ & $4(7.8)$ & $31(60.8)$ & $11(21.6)$ & $5(9.8)$ & - & 0.73 & $6^{\text {th }}$ \\
\hline $\begin{array}{l}\text { Absence of national } \\
\text { valuation standards }\end{array}$ & 10(19.6) & $17(33.3)$ & $20(39.2)$ & $4(7.8)$ & - & 0.72 & $7^{\text {th }}$ \\
\hline $\begin{array}{l}\text { Valuation } \\
\text { assumptions }\end{array}$ & $8(15.7)$ & $22(43.1)$ & $5(9.8)$ & $14(27.5)$ & $2(3.9)$ & 0.68 & $8^{\text {th }}$ \\
\hline $\begin{array}{l}\text { Familiarity with the } \\
\text { property market }\end{array}$ & $5(9.8)$ & $19(37.3)$ & $5(9.8)$ & $20(39.2)$ & $2(3.9)$ & 0.62 & $9^{\text {th }}$ \\
\hline
\end{tabular}

Source: Field survey 2017.

Table 7 shows that the problem of relevant data and the valuation methodology adopted are the major factors influencing mortgage valuation inaccuracy as indicated by responses of strongly agree, and thus ranked $1^{\text {st }}$ and $2^{\text {nd }}$ respectively. This finding is evident from the fact that access to the required data for valuation purposes is problematic in Nigeria (ONYEJIAKA, OLADEJO and EMOH 2015). Pressure exerted by the clients, the valuers' skills, regulatory framework, characteristics of the property market and absence of national valuation standards were ranked as the $3^{\text {rd }}$ to $7^{\text {th }}$ factors respectively affecting mortgage valuation inaccuracy, as shown by the agree responses of the respondents. On the other hand, respondents were undecided as to valuation assumptions and familiarity with the property market as factors affecting mortgage valuation inaccuracy, and these were, therefore, ranked as the $8^{\text {th }}$ and $9^{\text {th }}$ factors affecting mortgage valuation inaccuracy in the Kaduna residential property market. These findings agreed reasonably with the results of similar studies conducted by (AYUTHAYA, SWIERCZEK 2014; CHUKWUMA et al. 2015; EFFIONG 2015; ADEGOKE 2016; Olufolahan et al. 2016).

Factors affecting mortgage valuation inaccuracy were cross tabulated with the professional qualifications of respondents to examine the pattern of their responses as shown in Table 8 below.

Table 8

Cross-tabulation of factors with professional qualifications of respondents

\begin{tabular}{|c|c|c|c|c|c|c|c|c|c|}
\hline & & \multicolumn{8}{|c|}{ Professional Qualifications } \\
\hline & & \multicolumn{2}{|c|}{ ANIVS } & \multicolumn{2}{|c|}{ FNIVS } & \multicolumn{2}{|c|}{ PPNIVS } & \multicolumn{2}{|c|}{ Probationer } \\
\hline & & $\mathrm{F}$ & $\%$ & $\mathrm{~F}$ & $\%$ & $\mathrm{~F}$ & $\%$ & $\mathrm{~F}$ & $\%$ \\
\hline \multirow{5}{*}{ Valuation methodology } & $\mathrm{SD}$ & 0 & $0.0 \%$ & 0 & $0.0 \%$ & 0 & $0.0 \%$ & 0 & $0.0 \%$ \\
\hline & $\mathrm{D}$ & 0 & $0.0 \%$ & 0 & $0.0 \%$ & 0 & $0.0 \%$ & 1 & $6.7 \%$ \\
\hline & $\mathrm{U}$ & 0 & $0.0 \%$ & 1 & $33.3 \%$ & 0 & $0.0 \%$ & 0 & $0.0 \%$ \\
\hline & $\mathrm{A}$ & 14 & $45.2 \%$ & 0 & $0.0 \%$ & 0 & $0.0 \%$ & 9 & $60.0 \%$ \\
\hline & SA & 17 & $54.8 \%$ & 2 & $66.7 \%$ & 2 & $100.0 \%$ & 5 & $33.3 \%$ \\
\hline \multirow{3}{*}{ Problems of relevant data } & $\mathrm{SD}$ & 0 & $0.0 \%$ & 0 & $0.0 \%$ & 0 & $0.0 \%$ & 0 & $0.0 \%$ \\
\hline & $\mathrm{D}$ & 3 & $9.7 \%$ & 0 & $0.0 \%$ & 0 & $0.0 \%$ & 0 & $0.0 \%$ \\
\hline & $\mathrm{U}$ & 0 & $0.0 \%$ & 0 & $0.0 \%$ & 0 & $0.0 \%$ & 0 & $0.0 \%$ \\
\hline
\end{tabular}




\section{S sciendo}

\begin{tabular}{|c|c|c|c|c|c|c|c|c|c|}
\hline & $\mathrm{A}$ & 12 & $38.7 \%$ & 3 & $100.0 \%$ & 0 & $0.0 \%$ & 3 & $20.0 \%$ \\
\hline & SA & 16 & $51.6 \%$ & 0 & $0.0 \%$ & 2 & $100.0 \%$ & 12 & $80.0 \%$ \\
\hline \multirow{5}{*}{ Client pressure } & SD & 0 & $0.0 \%$ & 0 & $0.0 \%$ & 0 & $0.0 \%$ & 0 & $0.0 \%$ \\
\hline & $\mathrm{D}$ & 3 & $9.7 \%$ & 0 & $0.0 \%$ & 0 & $0.0 \%$ & 1 & $6.7 \%$ \\
\hline & $\mathrm{U}$ & 0 & $0.0 \%$ & 0 & $0.0 \%$ & 2 & $100.0 \%$ & 0 & $0.0 \%$ \\
\hline & A & 26 & $83.9 \%$ & 0 & $0.0 \%$ & 0 & $0.0 \%$ & 14 & $93.3 \%$ \\
\hline & SA & 2 & $6.5 \%$ & 3 & $100.0 \%$ & 0 & $0.0 \%$ & 0 & $0.0 \%$ \\
\hline \multirow{5}{*}{ Regulatory framework } & SD & 0 & $0.0 \%$ & 0 & $0.0 \%$ & 0 & $0.0 \%$ & 0 & $0.0 \%$ \\
\hline & $\mathrm{D}$ & 5 & $16.1 \%$ & 0 & $0.0 \%$ & 0 & $0.0 \%$ & 0 & $0.0 \%$ \\
\hline & $\mathrm{U}$ & 7 & $22.6 \%$ & 3 & $100.0 \%$ & 0 & $0.0 \%$ & 5 & $33.3 \%$ \\
\hline & $\mathrm{A}$ & 14 & $45.2 \%$ & 0 & $0.0 \%$ & 2 & $100.0 \%$ & 7 & $46.7 \%$ \\
\hline & SA & 5 & $16.1 \%$ & 0 & $0.0 \%$ & 0 & $0.0 \%$ & 3 & $20.0 \%$ \\
\hline \multirow{5}{*}{$\begin{array}{l}\text { Absence of national valuation } \\
\text { standards }\end{array}$} & SD & 0 & $0.0 \%$ & 0 & $0.0 \%$ & 0 & $0.0 \%$ & 0 & $0.0 \%$ \\
\hline & $\mathrm{D}$ & 0 & $0.0 \%$ & 3 & $100.0 \%$ & 0 & $0.0 \%$ & 1 & $6.7 \%$ \\
\hline & $\mathrm{U}$ & 17 & $54.8 \%$ & 0 & $0.0 \%$ & 2 & $100.0 \%$ & 1 & $6.7 \%$ \\
\hline & $\mathrm{A}$ & 6 & $19.4 \%$ & 0 & $0.0 \%$ & 0 & $0.0 \%$ & 11 & $73.3 \%$ \\
\hline & SA & 8 & $25.8 \%$ & 0 & $0.0 \%$ & 0 & $0.0 \%$ & 2 & $13.3 \%$ \\
\hline \multirow{5}{*}{$\begin{array}{l}\text { Skills, experience and } \\
\text { judgement of the valuer }\end{array}$} & SD & 3 & $9.7 \%$ & 0 & $0.0 \%$ & 0 & $0.0 \%$ & 0 & $0.0 \%$ \\
\hline & $\mathrm{D}$ & 0 & $0.0 \%$ & 0 & $0.0 \%$ & 0 & $0.0 \%$ & 0 & $0.0 \%$ \\
\hline & $\mathrm{U}$ & 12 & $38.7 \%$ & 3 & $100.0 \%$ & 2 & $100.0 \%$ & 0 & $0.0 \%$ \\
\hline & A & 7 & $22.6 \%$ & 0 & $0.0 \%$ & 0 & $0.0 \%$ & 6 & $40.0 \%$ \\
\hline & SA & 9 & $29.0 \%$ & 0 & $0.0 \%$ & 0 & $0.0 \%$ & 9 & $60.0 \%$ \\
\hline \multirow{5}{*}{$\begin{array}{l}\text { Characteristics of the property } \\
\text { market }\end{array}$} & SD & 0 & $0.0 \%$ & 0 & $0.0 \%$ & 0 & $0.0 \%$ & 0 & $0.0 \%$ \\
\hline & $\mathrm{D}$ & 3 & $9.7 \%$ & 0 & $0.0 \%$ & 0 & $0.0 \%$ & 2 & $13.3 \%$ \\
\hline & $\mathrm{U}$ & 6 & $19.4 \%$ & 3 & $100.0 \%$ & 2 & $100.0 \%$ & 0 & $0.0 \%$ \\
\hline & $\mathrm{A}$ & 19 & $61.3 \%$ & 0 & $0.0 \%$ & 0 & $0.0 \%$ & 12 & $80.0 \%$ \\
\hline & SA & 3 & $9.7 \%$ & 0 & $0.0 \%$ & 0 & $0.0 \%$ & 1 & $6.7 \%$ \\
\hline \multirow{5}{*}{ Valuation assumptions } & SD & 2 & $6.5 \%$ & 0 & $0.0 \%$ & 0 & $0.0 \%$ & 0 & $0.0 \%$ \\
\hline & $\mathrm{D}$ & 11 & $35.5 \%$ & 0 & $0.0 \%$ & 2 & $100.0 \%$ & 1 & $6.7 \%$ \\
\hline & $\mathrm{U}$ & 0 & $0.0 \%$ & 3 & $100.0 \%$ & 0 & $0.0 \%$ & 2 & $13.3 \%$ \\
\hline & $\mathrm{A}$ & 14 & $45.2 \%$ & 0 & $0.0 \%$ & 0 & $0.0 \%$ & 8 & $53.3 \%$ \\
\hline & SA & 4 & $12.9 \%$ & 0 & $0.0 \%$ & 0 & $0.0 \%$ & 4 & $26.7 \%$ \\
\hline \multirow{5}{*}{$\begin{array}{l}\text { Familiarity with the property } \\
\text { market }\end{array}$} & SD & 2 & $6.5 \%$ & 0 & $0.0 \%$ & 0 & $0.0 \%$ & 0 & $0.0 \%$ \\
\hline & $\mathrm{D}$ & 15 & $48.4 \%$ & 3 & $100.0 \%$ & 2 & $100.0 \%$ & 0 & $0.0 \%$ \\
\hline & $\mathrm{U}$ & 0 & $0.0 \%$ & 0 & $0.0 \%$ & 0 & $0.0 \%$ & 5 & $33.3 \%$ \\
\hline & A & 13 & $41.9 \%$ & 0 & $0.0 \%$ & 0 & $0.0 \%$ & 6 & $40.0 \%$ \\
\hline & SA & 1 & $3.2 \%$ & 0 & $0.0 \%$ & 0 & $0.0 \%$ & 4 & $26.7 \%$ \\
\hline
\end{tabular}

Source: Own study.

Table 8 above shows a cross tabulation between factors affecting mortgage valuation accuracy and the professional qualifications of respondents. The result shows that all the respondents agreed that valuation methodology is a factor contributing to mortgage valuation inaccuracy, although there were 33 percent undecided responses from fellow members of the Nigerian Institution of Estate Surveyors and Valuers. Similarly, all the respondents agreed on the problems of relevant data and client pressure as factors affecting inaccuracy. However, there are divergent views among the professionals on the regulatory framework and absence of national valuation standards as factors responsible for valuation inaccuracy. ANIVS and probationer members agreed as to the skills and experience of the valuer as well as valuation assumptions, while the rest were undecided. Only probationers agreed on familiarity with the property market as a factor affecting mortgage valuation inaccuracy, with the rest of the respondents disagreeing, as indicated by 57, 100 and 100 percent of such answers declared by ANIVS, FNIVS and PPNIVS respectively.

\subsection{Measure for reducing inaccuracy in mortgage valuation}

This section presents the results of proposed solutions to the problem of inaccuracy in mortgage valuation in the Kaduna residential property market as presented in Table 9 below. 


\section{S sciendo}

Table 9

Solutions to mortgage valuation inaccuracy in Kaduna

\begin{tabular}{|c|c|c|c|c|c|c|c|}
\hline 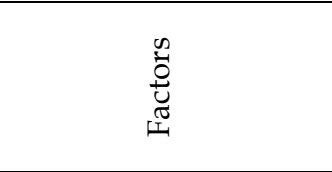 & 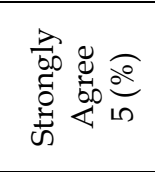 & 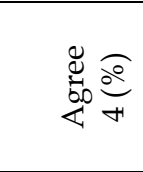 & 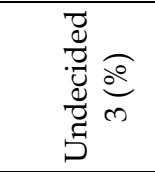 & 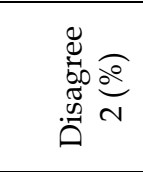 & 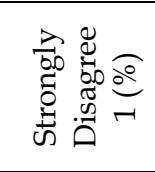 & RII & $\frac{\underline{\forall}}{\tilde{\Xi}}$ \\
\hline 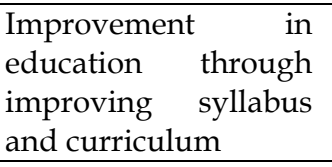 & $27(52.9)$ & $16(31.4)$ & $8(15.7)$ & - & - & 0.87 & $1^{\text {st }}$ \\
\hline $\begin{array}{l}\text { Creation of adequate } \\
\text { Data Bank on the } \\
\text { subject }\end{array}$ & $19(37.3)$ & $21(41.2)$ & 11(21.6) & - & - & 0.83 & $2^{\text {nd }}$ \\
\hline $\begin{array}{l}\text { Provision of valuation } \\
\text { standards and guide } \\
\text { line manual }\end{array}$ & $16(31.4)$ & $25(49)$ & $8(15.7)$ & $2(3.9)$ & - & 0.81 & $3^{\mathrm{rd}}$ \\
\hline $\begin{array}{l}\text { Quality of data } \\
\text { handling and proper } \\
\text { management }\end{array}$ & $16(31.4)$ & $24(47.1)$ & $9(17.6)$ & $2(3.9)$ & - & 0.81 & $4^{\text {th }}$ \\
\hline $\begin{array}{lr}\text { More } & \text { effective } \\
\text { regulatory framework }\end{array}$ & $8(15.7)$ & $38(74.5)$ & $5(9.8)$ & - & - & 0.81 & $5^{\text {th }}$ \\
\hline $\begin{array}{l}\text { Compliance with } \\
\text { ethical standards }\end{array}$ & $7(13.7)$ & $35(68.6)$ & $9(17.6)$ & - & - & 0.79 & $6^{\text {th }}$ \\
\hline $\begin{array}{ll}\text { Enforcement } & \text { of } \\
\text { NIESV code } & \text { of } \\
\text { conduct }\end{array}$ & $19(37.3)$ & $16(31.4)$ & $3(5.9)$ & $9(17.6)$ & $4(7.8)$ & 0.74 & $7^{\text {th }}$ \\
\hline $\begin{array}{l}\text { Specialization within } \\
\text { the profession based } \\
\text { on skills, knowledge } \\
\text { and experience }\end{array}$ & $15(29.4)$ & $14(27.5)$ & $12(23.5)$ & $6(11.8)$ & $4(7.8)$ & 0.71 & $8^{\text {th }}$ \\
\hline $\begin{array}{l}\text { Affiliation with } \\
\text { foreign professional } \\
\text { bodies }\end{array}$ & $9(17.7)$ & $17(33.3)$ & $14(27.5)$ & $11(21.6)$ & - & 0.69 & $9^{\text {th }}$ \\
\hline $\begin{array}{l}\text { Improving industrial } \\
\text { training and pupilage } \\
\text { training }\end{array}$ & $15(29.4)$ & $12(23.5)$ & $8(15.7)$ & $10(19.6)$ & $6(11.8)$ & 0.67 & $10^{\text {th }}$ \\
\hline $\begin{array}{l}\text { Compulsory } \\
\text { attendance of CPD }\end{array}$ & 7(13.7) & $14(27.5)$ & $12(23.5)$ & $16(31.4)$ & $2(3.9)$ & 0.63 & $11^{\text {th }}$ \\
\hline
\end{tabular}

Source: Field survey 2017.

Table 9 shows that the most important solution to the problem of mortgage valuation inaccuracy is improving the quality of education through syllabus and curriculum enhancement. The curriculum should be periodically reviewed to meet the changing needs of valuation practice. The creation of an adequate databank on the subject, provision of valuation standards and a guideline manual, quality of data/handling and proper management, more effective regulatory framework, compliance with ethical standards, enforcement of NIESV code of conduct, specialization within the profession based on skills, knowledge and experience, and affiliation with foreign professional bodies were ranked $2^{\text {nd }}$ to $9^{\text {th }}$ respectively as measures towards reducing/eliminating the problem of valuation inaccuracy in Kaduna. However, respondents were undecided on improving industrial training and pupilage training, as well as compulsory attendance of CPD, thus these ranking the lowest in the order of importance, i.e. the $10^{\text {th }}$ and $11^{\text {th }}$ factors respectively. 


\section{$\$$ sciendo}

\section{Conclusion}

The world is dynamic and driven towards competency with the market becoming increasingly globalized, thereby expecting a higher standard of practice from practitioners in the market of valuation. The profession has a duty to respond to the dynamics of market requirements through innovation and improving competencies as suggested by research findings if public confidence regarding the reliability of mortgage valuation is to be restored. This is because mortgage valuation has become an integral element of societal growth that no society, especially the study area, can ignore. The research identified the need to set measurable targets towards improving the accuracy of mortgage valuation in the study area.

\section{References}

ADEGOKE O. J., 2016. Effects of Valuation Variance and Inaccuracy on Nigerian Commercial Property Market An empirical Study, doi: 10.1108/JPIF-08-2014-0056,

Adegoke O. J., Olaleye A. OlOYedeS. A., 2013, A Study of Valuation Clients Perception on Mortgage Valuation Reliability, Adegoke, African Journal of Environmental Science and Technology 7(7), pp. 585-590,

AjIBOla M., 2006, The Accuracy of Investment Method of Valuation in Nigeria: A Case Study of Lagos. An unpublished M. Sc., University of Lagos.

Ajibola M., 2010, Valuation Inaccuracy: An Examination of Causes in Lagos Metropolis, Journal of Sustainable Development 3(4), p. 187,

Akinjare A. O., Ogunba O. A., Ayedun C. A., Iroham, C. O., 2013, Disamenity Hazards and Rental Values in durulere, Lagos Metropolis: a Perceptional Study of Power Lines, Ethiopian Journal of Environmental Studies and Management 6(1), pp. 96-103,

AluKo B. T., 2000, A Study of the Appropriateness of Mortgage Valuation for Institutional Lending in Nigeria, an Unpublished PhD Thesis, Obafemi Awolowo University, Ile-Ife, Nigeria,

AluKO B. T.,2004, Reliability of Mortgage Valuation for Institutional Lending in Nigeria practice in Nigeria, International Journal of Strategic Property Management 8(4), pp. 193-203. doi: 10.1080/1648715X.2004.9637517,

AluKO T., 2007, Implications of the Current Trend, International Journal of Strategic Property Management 11, pp. 17-31,

AyEDUN C., 2009, Reliability and Consistency of the Investment Method of Valuation: a Study of Lagos Metropolis, Convenant University,

Ayedun C. A., Oloyede S. A.,Durodola O. D., 2012, Empirical Study of the Causes of Valuation Variance and Inaccuracy in Nigeria, International Business Research 5(3), pp. 71-80. doi: 10.5539/ibr.v5n3p71,

AYUTHAYA N. P.,SWIERCZEKF. W., 2014, Factors Influencing Variation in Value and Investors Confidence, IOSR Journal of Business and Management 16(5), pp. 41-51,

BABAWALE G., 2008, An Evaluation of Factors Influencing Inaccuracy in Residential Property Valuation in Lagos Metropolis, Unpublished PhD Thesis Submitted to the Department, University of Lgos,

BabaWAle G., 2013, Valuation Accuracy - the Myth, Expectation and Reality!, African Journal of Economic and Management Studies 4(3), pp. 387-406, doi: 10.1108/AJEMS-11-2011-0106,

BabaWale G. K.,Alabi A. A., 2013,The Nexus between Valuation Accuracy and Mortgage Finance: A Nigerian perspective, Journal of Transformative Entrepreneurship 1(1), pp. 1-13,

BABAWALE G. K., OMIRIN M., 2012, An Assessment of the Relative Impact of Factors Influencing Inaccuracy in Valuation, International Journal of Housing Markets and Analysis 5, pp. 145-160, doi: 10.1108/17538271211225904,

Brown G. R., MATYSiAK G. A., 2000,Sticky Valuations, Aggregation Effects, and Property Indices, The Journal of Real Estate Finance and Economics 20(1), pp. 49-66, doi: 10.1023/A:1007879805481,

ChuKwuma Nwuba C. S. U., Babatunde E., SAlaWU M., 2015, Clients' means of influence on mortgage valuation in Nigeria,Property Management Vol. 30 No(ISS), pp. 367-385, doi: http://dx.doi.org/10.1108/PM-03-2014-0016,

EFFIONG J. B., 2015a, A Comparative Study of Valuation Variance and Accuracy Between Nigeria and UK, International Letters of Social and Humanistic Sciences 57, pp. 94-105, doi: 10.18052/www.scipress.com/ILSHS.57.94,

KUCHARSKA - STASIAK E., 2013, Uncertainty of Property Valuation as a Subject of Academic Research, Real 
Estate Management and Valuation 21(4), pp. 17-25, doi: 10.2478/remav-2013-0033,

Munshifwa E. K., Jain N., Kaunda B. S., Masiba L., Lungu J., Chunda-Mwango N., Mushinge A.,Ngoma W., 2016, Variances in Rateable Values in Rating Practice in Zambia: the Role of Mental Models in Value Assessment, Pacific Rim Property Research Journal, Routledge, 22(2), pp. 181-201, doi: 10.1080/14445921.2016.1225151,

Ogunba O.A., \& C. A. A., 2007, The Response of Nigerian Valuers to Increasing Sophistication in Investors' Requirements, Journal of Property Investment \& Finance 25(1), pp. 43-61, doi: 10.1108/14635780710720162,

Ogunba O., Ajayi C., 1998, An Assessment of the Accuracy of Valuations in the Residential Property Market of Lagos, The Estate Surveyor and Valuer 21(2), pp. 19-23,

Olufolahan O., Michael O., OluWaseun F., 2016, Property Valuation Inaccuracy in Commercial Office Buildings: Establishing the Key Causative Factors, International Journal of Real Estate Studies 10(1), pp. 1-11,

Oluwunmi A.O., Ajayi C.A., Olaleye A., Fagebnle O. I., Oluwunmi A., Ajayi C.,Olaleye A., 2011, An Analysis of Clients' Satisfaction with Mortgage Valuation Reports in Nigeria, International Journal of Marketing Studies 3(2), pp. 160-168, doi: 10.5539/ijms.v3n2p160,

OnyejakA J. C., Oladejo E. I.,EMOH F. I., 2015, Challenges of Using the Cost Method of Valuation in Valuation Practice: a Case Study of Selected Residential and Commercial Properties in Awka and Onitsha, Anambra State, Nigeria, International Journal of Civil Engineering, Construction and Estate Management 3(2), pp. 16-35,

OSMOND C., HARCOURT P., 2014, Challenges of Mortgage Valuation in Port Harcourt, 2(April), pp. 74-79.

Pallant J., 2011, A Step by Step Guide to Data Analysis Using SPSS, Alen \& Unwin, p. 359, doi: 10.1046/j.1365-2648.2001.2027c.x.,

PARKer D. R., 1998,Valuation Accuracy - an Australian Perspective, in 4th Pacific Rim Real Estate Society Conference, Perth,

Rossini P., 1999, Accuracy Issues for Automated and Artificial Intelligent Residential Valuation Systems, in International Real Estate Society Conference, Kuala Lumpur, pp. 26-30,

SHEHU J., 2016, Assessment of Factors Influencing Valuation Inaccuracy in Abuja Residential Property Market Universiti Teknologi Malaysia, Universiti Teknologi Malaysia,

WALLEY S., 2009, Making Finance Work for Nigeria, World Bank Report on Housing. 